\title{
Leder
}

\section{Mat - teknologi, sikkerhet og rettferdighet}

\section{Bjørn K. Myskja, Rune Nydal \& Berge Solberg}

Mat er så mangt, som David Kaplan påpeker i innledningen til The Philosophy of Food, blant annet næring, natur, kultur, et sosialt gode, åndelighet, begjærsgjenstand og estetisk objekt. Ikke minst er det et politisk tema på så mange måter. Derfor inviterte vi til et temanummer om matens etikk, for det er lite som berører våre liv så sterkt og fundamentalt som mat. Det er et område som til alle tider har hatt tydelige etiske regler, både hva man kan og ikke kan spise, men også hvordan man skal behandle mat. I Første Mosebok står det: «Med svette i ansiktet skal du spise ditt brød». Vi gjør oss fortjent til å spise gjennom vårt arbeid. Til det er det også knyttet sterke tradisjoner rundt det å dele mat, takke for den, behandle den med respekt og ikke la noe gå til spille. Dette er tradisjoner som står stadig svakere ettersom vår kontakt med opphavet til mat i jordbruk, jakt og fiske blir svekket. Vi står ikke lenger i et direkte og intimt forhold til maten i vår del av verden, og det får betydning for matens etikk.

Vi er avhengig av god og sikker tilgang på mat som produseres, foredles og oppbevares på måter som gjør at maten når fram til alle, beholder sin næringsverdi og ikke er helseskadelig. I en verden med stadig økende folketall og forskjeller på fattig og rik har ulike aspekter av produksjonslinjen fra produsent til forbruker blitt etisk og politisk brennbare tema. Den økte industrialiseringen av matproduksjonen som kombineres med stadig nye teknologier, får også betydning for vår tilknytning til mat som kulturell faktor. Vi står i et tilsynelatende dilemma der problemene med å skaffe nok mat fører til utvikling av nye teknologiske løsninger som flertallet er skeptiske til - i alle fall så lenge de ikke ser behovet. Vi som er storforbrukere av den av maten som produseres, ser stort sett ikke behov for økt produksjon, vi har så altfor mye av den. I den rike verden er for høyt forbruk og spiseforstyrrelser problemet, ikke mangel på mat. Derfor har teknologiske løsninger på matmangel en vanskelig vei til aksept, ettersom de rike markedene de behøver for sine produkter, ikke er mottakelige for dem.

Denne intensive industrialiseringen og teknologiseringen av matproduksjon skjer parallelt med en rekke andre, til dels motstridende utviklinger på matfeltet. I den vestlige verden vil vi både ha billig mat som er enkel å tilberede, samtidig som den skal være kulturelt verdifull. Dermed får vi bevegelser for økologisk produksjon, kortreist mat, «langsom mat» og vektlegging av sesongens råvarer og tradisjoner, samtidig som ferdig tilberedte måltider for oppvarming i mikrobølgeovn er et voksende marked. Vi kan si at vår respekt for mat vokser og reduseres på samme tid.

Den første artikkelen i dette temanummeret om mat tar for seg et fenomen som blant annet kan forstås som et utslag av denne manglende respekten for mat. Vi spiser ikke opp all maten vi skaffer oss, og kaster mye av den selv om den fortsatt er velegnet som menneskeføde. Med sin artikkel «Food waste in Nordic countries: estimations and ethical 
implications» ønsker imidlertid ikke Mickey Gjerris og Silvia Gaiani å bidra til moralisering over denne typen overforbruk som har blitt en del av levemåten i den rike del av verden. Med utgangspunkt i tilgjengelig empiri analyserer de omfanget og den økonomiske betydningen av matsløsingen og foreslår mulige årsaker til fenomenet. De påpeker at selv om det i et globalt perspektiv er irrelevant om vi kjøper mer klær eller mer mat enn vi bruker, framstår det siste som verre i den allmennmoralske vurderingen. Forfatterne hevder det er et misforhold mellom de rasjonelle forståelsesformene vi bruker på dette fenomenet, og den sterkt negative reaksjonen, og de forklarer denne moralske dommen eksistensielt: Sløsing med mat berører vår grunnleggende erfaring av menneskelig eksistens som integrert del av naturen som er grunnlaget for våre liv, en natur som er verdifull i seg selv. Det å kaste mat kan fortolkes som en forkastelse av vår delaktighet i en slik helhetlig natur, og dermed som en instrumentalisering av naturen. Dersom det er riktig, vil ikke en snever moralistisk tilnærming til kasting av mat, der vi påpeker de økonomiske, økologiske og rettferdighetsmessige implikasjonene av denne adferden, kunne endre vår praksis. En mer grunnleggende endring av vår selvforståelse, der vi ser vår deltakelse i en større enhet, vil derimot kunne gi grunnlag for mer dyptgripende forandringer. Dersom Gjerris og Gaiani har rett, er det en verdensforståelse beslektet med økosentrisk tenkning som gir vekt til vår moralske reaksjon på sløsing med mat. Et slikt perspektiv innebærer at vi verdsetter og er takknemlig for maten, heller enn å se den som en ressurs vi kan bruke eller forkaste etter egne ønsker.

Sløsing med mat kan inkludere andre fenomen enn bare det å kaste den. I et helhetlig perspektiv er det å spise kjøtt heller enn grønnsaker og korn en annen form for sløsing, fordi kjøttproduksjon krever langt større areal og energitilførsel enn produksjonen av tilsvarende mengder vegetabilsk føde. Dessuten er det veldokumentert at store deler av det moderne, industrielle husdyrholdet innebærer dårlig dyrevelferd. Imidlertid er det lite sannsynlig at en vesentlig del av menneskeheten vil omfavne en vegetarisk livsstil i overskuelig framtid, særlig ettersom kjøttforbruket stiger i land der velstanden øker. I artikkelen «The new meat. Problems and prospects» analyserer Stellan Welin de etiske aspektene ved en mulig løsning på motsetningene mellom bærekraftig matproduksjon og dyrevelferd på den ene siden og vår trang til kjøttmat på den andre: produksjon av kunstig kjøtt. Dette tredje stadiet i kjøttproduksjon innebærer å utvikle muskelvev av stamceller fra dyr, altså ved å dyrke kjøtt i laboratoriet. Det er store tekniske utfordringer, og det gjenstår å se om det er mulig å gro kjøtt som er rimelig og aksepteres av forbrukerne, men det er gevinster ved denne teknologien. De åpenbare fordelene for miljø og dyrevelferd tilsier at dette er en mulighet som bør forfølges. Forfatteren diskuterer innvendinger, blant annet at slik matproduksjon er unaturlig. Det er riktig nok, men man kan spørre om ikke moderne industriell kjøttproduksjon er mer unaturlig. Tilsvarende er det med innvendingen om at denne formen for matproduksjon vil fremmedgjøre oss fra naturen. Ifølge forfatteren er det ikke mer fremmedgjørende enn de dominerende formene for kjøttproduksjon. Welin hevder at det er noen reelle spørsmål knyttet til om denne teknologien kan levere det den lover, og det er også noen uløste spørsmål angående risiko og uforutsette negative hendelser, men ingen av disse er så vektige at de bør hindre videre forskning på dette feltet. 
Som sagt er nye teknologiske løsninger innen matproduksjon og distribusjon nødvendig for matsikkerhet, samtidig som det er stor skepsis til noen former av teknologisering av dette feltet. Derfor er det viktig å utvikle gode, helhetlige kontrollsystemer for nye matteknologier. Det vil både forhindre skade og sikre aksept der det er grunnlag for det. I artikkelen «Integration needs in assessments of nanotechnology in food and agriculture» analyserer Ellen Marie Forsberg og Carolien de Lauwere muligheten for å benytte integrerte vurderingssystemer utviklet for bærekraft for vurdering og regulering av nanoteknologi i mat og jordbruk. De påpeker både muligheter og usikkerhet ved dette relativt nye og lite utforskede knippe av teknologier, og dokumenterer behovet for nye reguleringssystemer. Selv om integrerte vurderinger er en veletablert praksis innen $\mathrm{EU}$, påpeker forfatterne en rekke ulike forståelser og systemer for integrering. Ved å systematisere og lage en begrunnet innsnevring med henblikk på nanoteknologi i mat og jordbruk, kommer de fram til en håndterbar liste som de anvender på en rekke nederlandske og internasjonale vurderinger på dette feltet. Gjennom en grundig analyse og diskusjon, der mulige fallgruver ved bruk av integrerte vurderinger belyses, viser de at det er potensial for bedre vurderingssystemer på dette feltet, og de framhever særlig behovet for å ta lærdom av eksisterende vurderinger og for å styrke genuin tverrfaglighet.

Den siste artikkelen i temadelen tar for seg det som kanskje er den største utfordringen innen matens etikk. Et av de skammelige forholdene vi står overfor som verdensborgere, er at store deler av jordens befolkning sulter, til tross for at det produseres nok mat på kloden til å brødfø alle. Det er stadig flere mennesker som ikke får nok næring, selv om den relative andelen har gått ned. Hans Morten Haugen reiser det betimelige spørsmålet om hvordan en kan komme ut av denne situasjonen i artikkelen «Kampen om matfatet og matproduksjonen». Haugen argumenterer for at det finnes to strategier for utrydding av sult som står i et spenningsforhold til hverandre. På den ene siden har vi dem som retter fokus mot teknologiske løsninger for økt matproduksjon (f.eks. bioteknologiske) og handelsstrukturer som kan sikre matdistribusjon. På den andre siden har vi dem som fokuserer på konkrete sosiale og politiske virkemidler som hindrer at mennesker får den maten de trenger. Der den første strategien dreier oppmerksomheten mot tekniske løsninger for økt produksjon og distribusjon som sådan, vil den andre strategien være mer orientert mot målrettede løsninger som tar utgangpunkt i situasjonen til dem som sulter og som faktisk ikke har tilgang til mat. Haugen argumenterer for at en ikke kan få bukt med sultproblemet om en ikke anser det som en borgerrettighet å få tilstrekkelig med næring. Det bør ikke kun handle om spørsmål som rettferdig fordeling, men om en rettighet som eksempelvis må forplikte de enkelte staters strategier og prioriteringer. Spørsmål om hvordan man kan skape teknologiske muligheter for økt matproduksjon og bedre distribusjonskanaler, kan således risikere å stå i et motsetningsforhold, eller maskere spørsmålet om hva som forhindrer at borgeres basale rett til mat settes i høysetet, og er retningsgivende for strategier for å løse sultproblemet. 


\section{Åpen del: Global fordeling og fair play i skolen}

Teppo Eskelinens artikkel «Living with the extreme demand» tar opp et tema som er beslektet med Haugens, nemlig spørsmålet om hva slags forpliktelser vi i den rike delen av verden har overfor de som lider nød. Hans utgangspunkt er Peter Singers radikale krav til oss i den rike verden om å donere en vesentlig del av vår inntekt til verdens fattigste. Eskelinen gir Singer rett mot sine kritikere; vi har en plikt til å gi inntil den grensen der tilfredsstillelse av egne grunnleggende behov er i fare. Et menneskeliv er alltid viktigere enn de ønskene vi måtte ha - utover å tilfredsstille våre egne grunnleggende behov. Forfatteren avviser de vanlige innvendingene mot Singers argument - at dette er et politisk, ikke-individmoralsk problem, og at det er moralpsykologisk urealistisk og derfor heller bidrar til å undergrave verdien av moralske forpliktelser generelt. Eskelinens innvending mot Singer er i stedet at han ikke gir en rimelig beskrivelse av velstanden i den rike delen av verden. Livet $i$ et moderne, kapitalistisk samfunn preges av at en rekke sosiale nødvendigheter bestemmer hva det innebærer å dekke grunnleggende behov. Både transport, utdannelse, sosial interaksjon og kommunikasjonsmidler er kostbare betingelser for å overleve i dette samfunnet. Dermed vil mulighetsrommet for å donere av et inntektsoverskudd være langt mindre enn det Singer forutsetter. Dersom man tar høyde for konteksten av sosiale nødvendigheter, vil det være god grunn til å ta Singers argument til følge, ifølge Eskelinen.

I den siste artikkelen er temaet «fair play». Det er imidlertid verken breddeidrett eller toppidrett som er arenaen for artikkelforfatter Ove Sæles fair play-diskusjoner. Snarere er det kroppsøvingsfaget i norsk skole - et fag hvis hensikt slett ikke er åpenbar, og som mange generasjoner av elever har hatt et elsk- eller hatforhold til. I den nye reviderte norske kroppsøvingsplanen har fair play kommet tungt inn, og fair play omfatter angivelig aspekter ved idrettsspillet som å overholde regler, vise hverandre respekt og gjøre hverandre gode. Hva betyr så dette, spør Sæle, før han setter ord på og formulerer en rekke spennende svar inspirert av planen. Det er ikke tekniske idrettsferdigheter kroppsøvingsfaget primært skal utvikle eller karaktermessig belønne. I kroppsøvingsfaget skal man «gjøre hverandre gode», og det er det «gode spillet» hvor kollektive og moralske kvaliteter står sentralt, som skal belønnes. Kroppsøvingsfaget skal være et dannelsesfag hvor aristoteliske dyder som rettferdighet, mot, måtehold og klokskap skal ha en sentral plass. Mange brudd på fair play-regler skyldes manglende besinnelse, manglende mot og svake vurderinger og handlinger i opphetede kampsituasjoner, hevder Sæle, og dette gjelder like mye i skolens gymtimer som i toppidretten. Med kroppsøvingsfaget trygt forankret i en humanistisk tradisjon med fokus på bevegelsesglede og bevegelsesmangfold, og ved at det er en «fristat» fra en instrumentell skolehverdag, ser Sæle positivt på framtiden til faget. Vi deler Sæles syn. Mål og mening med kroppsøvingsfaget har endelig falt på plass. Nå gjelder det bare at lærerne leser både Sæle og den nye kroppsøvingsplanen. 


\section{Redaktorskifte}

Tidsskriftet Etikk i praksis. Nordic Journal of Applied Ethics har kommet med nytt nummer én gang i halvåret siden høsten 2007, hele tiden med samme redaktører. Formålet med tidsskriftet var å fremme den fellesnordiske diskusjonen av anvendt etikk gjennom artikler av god vitenskapelig kvalitet. Vi mener vi har oppnådd det gjennom disse årene. Tidsskriftet er nå veletablert som open access-tidsskrift med en jevn tilgang av artikler fra et bredt utvalg av fagfelt og alle nordiske land. Vi er svært takknemlige for all hjelp og støtte vi har fått fra våre redaksjonssekretærer, redaksjonsrådet, kolleger som velvillig har stilt opp som fagfellegranskere, og for samarbeidet med Akademika forlag, tidligere Tapir Akademisk Forlag.

Vi overlater med glede redaksjonsansvaret til våre kolleger May Thorseth, Siri Granum Carson og Charles Ess og vet at tidsskriftet er i trygge hender. Takk for oss! 